\title{
Demography, Activity Pattern, Food and Feeding Habits of Primates in Nilgiris, Tamil Nadu, India
}

\author{
Veeramani $\mathrm{A}^{1 *}$, Pushpalatha $\mathrm{KB}^{2}$, Mohanakrishnan $\mathbf{H}^{2}$, \\ Ramakrishnan B2 ${ }^{2}$, Santhoshkumar P2, Samsan A² and Karthick S2 \\ ${ }^{1}$ Department of Zoology, Government Arts College (Autonomous), India \\ 2Department of Zoology and Wildlife Biology, Government Arts College, India \\ Research Article \\ Volume 2 Issue 1 \\ Received Date: December 27, 2018 \\ Published Date: January 04, 2019 \\ DOI: $10.23880 /$ izab-16000132
}

*Corresponding author: Veeramani Arunachalam, Department of Zoology, Government Arts College (Autonomous), Kumbakonam-612002, India, Tel: +91-8124881520; Email: wildveera@gmail.com

\section{Abstract}

The Western Ghats of South India has a highly fragmented population of India's most endangered primate species viz. the lion-tailed macaque (Macaca silenus) and Nilgiri langur (Trachypithecus johnii). The distribution of Common or Hanuman langur (Semnopithecus entellus) extends up to the southern region of the Western Ghats. Peninsular India holds two other primate species, the bonnet macaque (Macaca radiata) and the slender loris (Loris tardigradus). This is the first attempt to conduct the distribution of south Indian primates in and around Gudalur region, The Nilgiris. The study area was perambulated to locate the primates to know the status and distribution of these animals. Data on troop structure, composition and sex ratios were attempted. Behavioral data of primates were collected using focal animal sampling. Comparison of age and sex class of the adult female of all three primates such as bonnet macaque, common langur and Nilgiri langur is higher than the adult males. Similarly comparison of habitat selection shows that bonnet macaque and common langur prefers mostly on plantations followed by moist deciduous habitat. Whereas the Nilgiri langur prefer mostly on shola forests. The result of different activities shows that all these three primates spent most of time on resting activities followed by feeding. Statistical analysis of One-way ANOVA shows that there are significant differences among the three species of primates on Age-sex classes, activity pattern and feeding habits. Detailed studies that combined field surveys and phylogenetic studies are needed to determine the primate distribution and status in the rain forests.

Keywords: Western Ghats; Nilgiris; Primates; Activity Pattern; Demography; Feeding

\section{Introduction}

The Western Ghats, a series of hill ranges, run parallel to the western coast of southwestern India [1]. Being close to the Arabian Sea, they receive heavy southwest monsoons. Whereas the western slopes and the ridges contain primarily tropical evergreen rain forests whereas the eastern slopes, which are in a rain shadow, contain deciduous and scrub forests. The Ghats, with a length of about $1600 \mathrm{~km}$ from north to south and with an east to west width of $30-80 \mathrm{~km}$, are a mosaic of heterogeneous habitat types. Although humans have been active in the 


\section{International Journal of Zoology and Animal Biology}

hills since prehistoric times, organized state sponsored forestry and non-forestry activities began about 200 years ago [2]. The anthropogenic activities such as cultivation of commercial plantations, tea and coffee, construction of dams and hydro power generation, brought millions of people to these hills. Consequently, natural habitats have undergone drastic changes. The most conspicuous effect of human pressure has been fragmentation of the rain forests. In most places, the rain forests fragments are isolated because of gaps created by plantations and commercial crops. However, the Western Ghats still harbor a diversity of plant and animal life, because of which they are one of the 8 hottest hotspots of biodiversity in the world.

Distribution of eight primate genera consisting of 18 species shows remarkable primate diversity in India. Of these six species are exclusively Indian in their distribution. Among the rest seven are also found in adjacent countries like Afghanistan, Pakistan, Nepal, Bhutan and Myanmar. However the remaining five species have got restricted distribution in southern India [3]. The Western Ghats provide a striking example of primate endemism and it holds a highly fragmented population of India's most endangered primate species namely the lion-tailed macaque (Macaca silenus) and Nilgiri langur (Trachypithecus johnii). The distribution of Common or Hanuman langur (Semnopithecus entellus) extends up to the southern region of the Western Ghats [4]. Peninsular India holds two other primate species the bonnet macaque (Macaca radiata) and the slender loris (Loris tardigradus). A few field surveys were carried out elsewhere to estimate the status of these primate populations in the Western Ghats [5-14]. This is the first attempt to conduct the distribution of south Indian primates such as Bonnet Macaque, Hanuman Langur and Nilgiri Langur in the surrounding areas of Gudalur region, The Nilgiris.

\section{Description of the Study Animals}

\section{Bonnet Macaque (Macaca radiata)}

It is an endemic species to southern India. The species that is largely arboreal found in all types of habitat, especially those created and maintained by human beings. The estimated population size of the macaque is around 170,000 in just the four southern states, of which Tamil Nadu is known to be home to about 16,000 individuals [15]. Amongst primates found in southern India, bonnet macaque is the only species that often gets into conflicts with people in both urban and rural areas (Figure 1).

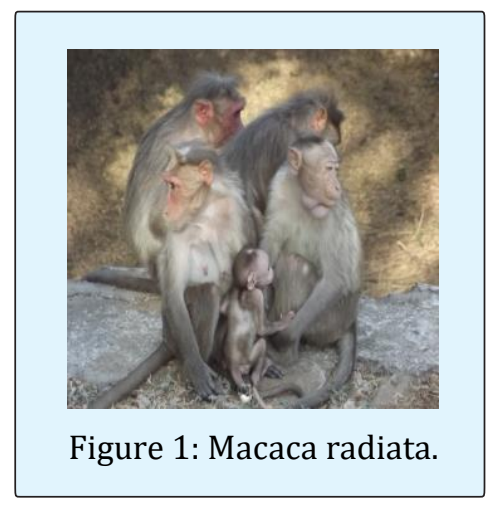

The bonnet macaque usually lives in multi-male \& multi-female troops; the troop size varies from 9 to 41 individuals. According to Roonwal \& Mohnot (1977) [4] and Kurup (1981) [15] the troop size varies from 5 to 75 individuals in the wild. Although troop size may be highly variable in a particular ecological area, it tends to be much smaller in natural forests and significantly larger in or near human habitation [16,17]. Each troop typically consists of one to several adult males and females and a variable number of sub-adults, juveniles and babies (infants) of both sexes. Similarly the ratio of different agesex classes within troops shows some variation across ecological habitats the most interesting aspect being the adult males to adult female's ratio $[18,19]$.

\section{Common or Hanuman Langur (Semnopithecus entellus)}

Hanuman or common langur is ubiquitously distributed arboreal mammal in the Indian subcontinent [20]. This richness mirrors the biological and environmental diversity of the country, its ranging from mountain habitats in the Himalayas, the Semiarid regions, agricultural plains of the Gangetic basin, subtropical forests of the northern India, tropical dry deciduous of Deccan plateau, tropical forests of South India (Figure 2) [21].

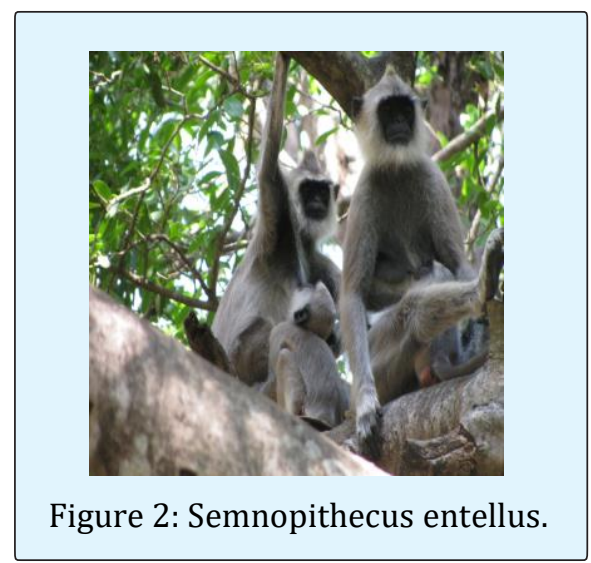

Veeramani A, et al. Demography, Activity Pattern, Food and Feeding Habits of Primates in Nilgiris, Tamil Nadu, India. Int J Zoo Animal Biol 2019, 2(1): 000132. 
Hanuman langur is important components of the Indian biota, culture and its mythology believes the monkey god. However the Hanuman langur is one of the preferable prey species for large carnivores [22]. The comparatively higher degree of predation on langur by leopard may be linked to the leopard's greater arboreality and crypticity in comparison to the tiger [22]. On the other hand, dholes, which openly course after their prey in packs, are least likely to capture langur [23]. They play a vital role in both the natural and the cultural environments, and have contributed to the health and welfare of the entire ecosystem by virtue of their role in scientific research. However the Hanuman langur studied by several researchers in the Indian subcontinent but there has been no previous study on Hanuman langur and nothing is known about its population density and their abundance in Gudalur region of Nilgiris. This study is the first attempt to present a comprehensive investigation on the population density, group size and abundance of Hanuman langur in this region. The results are intended to provide the baseline source for conducting further studies about this important arboreal species.

\section{Nilgiri Langur (Trachypithecus johnii)}

Nilgiri langur is a threatened black faced colobine that is endemic to Western Ghats in South India. Colobines have a complex foregut, stub thumb and a long tail that distinguish them from other monkeys (Figure 3). Nilgiri langur was earlier placed under genus Presbytis, and subsequently placed under genus Semnopithecus. However, it is currently included in the genus Trachypithecus. Its position is debatable as recent studies indicate that Nilgiri and Purple faced langur are more closely related to Hanuman langur rather than leaf monkeys of South-east Asia and hence should be placed under genus Semnopithecus.

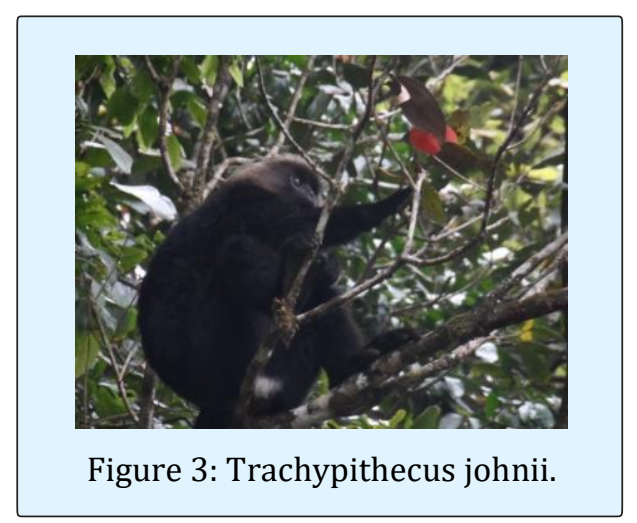

The Nilgiri Langur is endemic to the southern portion of the Western Ghats in south India. The species ranges from Kanyakumari to Coorg hills, Srimangla range of Brahmagiri-Makut protected area forming its northernmost limit in the Western Ghats. Its range states thus include Kerala, Karnataka and Western Tamil Nadu. The species has been listed under Appendix II of CITES. They are also protected under the Schedule I, Part I of Indian Wild Life (Protection) Act, 1972 and are listed as Vulnerable under IUCN Red data list. The key to conservation of this species lies in reducing poaching, protecting their habitat and education of masses.

\section{Objectives}

The objectives of the study on primates in the villages surrounded by natural forest areas of Gudallur region were

$>$ To monitor the abundance

$>$ To study the habitat usage

$>$ To study the activity pattern and

To study the food and feeding habits of the primates.

\section{Study Area}

The study sites include the village areas around Chundi, Bennai, Padanthurai, Puliyamparai, Naduvattam and Thorapally regions are adjacent to Gudalur Taluk of Nilgiris, Tamil Nadu. The surrounding forest type in Bennai and Chundi regions are predominantly evergreen habitat. Whereas the Padanthorai region falls in deciduous forests and most of the villages falls in agricultural fields. In Puliyanparai, Thorapally and Srimadurai regions falls under mixed type of deciduous vegetations and the adjacent villages has few plantations. In the case of Naduvattam has fragmentation of shola vegetation and predominantly tea estates.

Champion and Seth (1968) [24] classified the vegetation type in the surrounding of the study area as, Southern Tropical moist deciduous forest, Southern Tropical semi-evergreen, moist bamboo brakes and Riparian fringing forest. The trees found in Southern Tropical dry deciduous forest shed their leaf during dry season and it is prone to fire during dry season. The common tree species are Anogeissus latifolia, Grewia tilifolia, Terminalia crenulata, T. tomentosa, Kydiya calycina and Tectona grandis. Moist deciduous forest is found in regions where the rainfall is between 1600 and $2000 \mathrm{~mm}$. This type of forest is found in Benne, in Mudumalai. The canopy is closed in this forest and the trees are tall. The common tree species in moist deciduous forest includes Lagerstroemia microcarpa, Terminalia crenulata, Tectona grandis and Dalbergia latifolia. 
A bit of semi evergreen forest is found in the Southwest and Western part of the study area. The rainfall in this region exceeds $2000 \mathrm{~mm}$. The tree species in this habitat includes Olea dioca, Glochiodion velutinum, Toona ciliate, Elaeocarpus tuberculatus, Casseria ovoides, Litsea mysorensis and Cinnamomum malabaricum. The plant species found in riparian forests includes Mangifera indica, Pongamia glabra, Terminalia arjuna, Bischofia javanica, Linociera malabarica, Syzygium cumini, Dalbergia latifolia, Bambusa arundinacea and Dendrocalamus strictus. The fauna consists of diverse wildlife population which includes elephant, gaur, leopard, wild dog, deer's, monkeys, etc. with varied avifauna and reptiles.

\section{Methods}

The study area was perambulated to locate the primates and to know the status and distribution of these animals. Data on troop structure composition and sex ratios were also attempted. The individuals were classified as adult male, adult female, and sub adult male, sub adult female, juvenile and cradled infant $[25,26]$. Individuals which cannot be classified pertaining to any of the above class were grouped into unidentified adults. The primate population was estimated using a combination of total count and sweep sampling methods $[27,28]$. Repeated surveys were conducted on foot in each area to count troop size, structure and sex-ratio.

The present study was followed the observational methods used in several previous studies [29-31]. Behavioral data were collected using focal animal sampling [32]. A selected monkey was followed and observed. Activities of the monkey were recorded at 30second intervals as long as the monkey was visible. Thirty seconds were considered the minimum time necessary for recording activities of an individual. The number of records made at 30-second intervals during which the animal engaged in each activity will be referred to as "time spent" in that activity [32]. The following categories describe activities.

1. Resting: sitting, lying, or sleeping on branches

2. Feeding: searching for food.

3. Parental Care.

4. Walking

5. Jumping

6. Playing.

The feeding behaviour of the primates was studied along with the observation on behavioral activities. During the focal animal sampling, the feeding activities of each primate species were observed and the different types of food items such as leaves, shoots, flowers, fruits, barks, insects and other unknown items consumed were recorded. The data analysis on feeding behaviour was carried out as feeding events on observation time and computing the percentage of foraging devoted to a specific plant part [32]. Each time they switched food items were used for this feeding analysis. The percentage of foraging frequency devoted to a specific plant part was calculated as the total feeding events that item consumed divided by the total amount of feeding events recorded [33]. Diet selection of the study troops was determined from the relative proportion of the feeding events on different food items.

\section{Data Analysis}

Statistical tests were conducted using Microsoft Excel and PAST (Paleontological Statistics) software. One-way ANOVA was used to examine the significance of the differences between means. The time spent on each category of activity was calculated by summing the total number of recorded observations for each category and expressing it as a percentage of the total number of all recorded observations.

\section{Results}

\section{Abundance Estimation}

The group composition of Bonnet macaque in the study area shows that maximum sighting of individuals sighted are adult female (156) followed by adult male (88) and young (70). Moderate sightings of sub adult male (56), sub adult female (39) and juvenile (55) were seen in all the study areas Figure 4. The sex ratio of adult male and adult female is around 1:2.

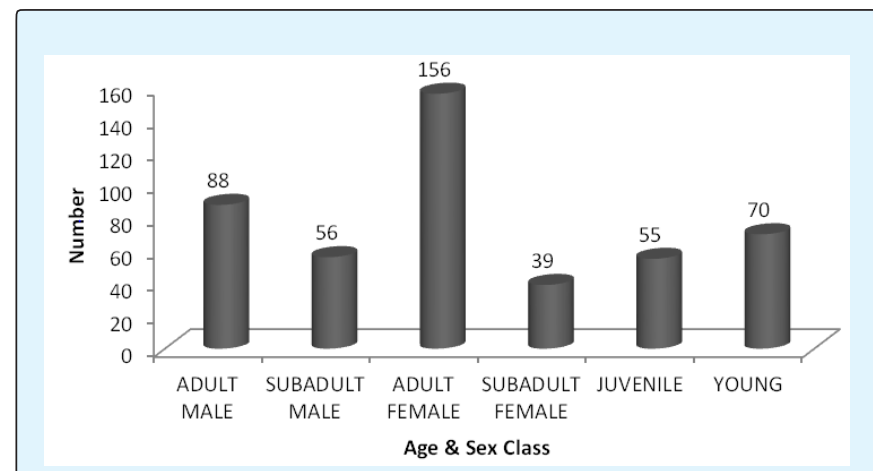

Figure 4: Group Composition of Bonnet Macaque.

In the case of Common langur the group composition of adult female is high (39) whereas the adult male is only 


\section{International Journal of Zoology and Animal Biology}

(15). The sex ratio of adult male and female is $1: 2.6$. The sub adult female, juvenile and young ones of common langur seen almost equal in number (Figure 5).

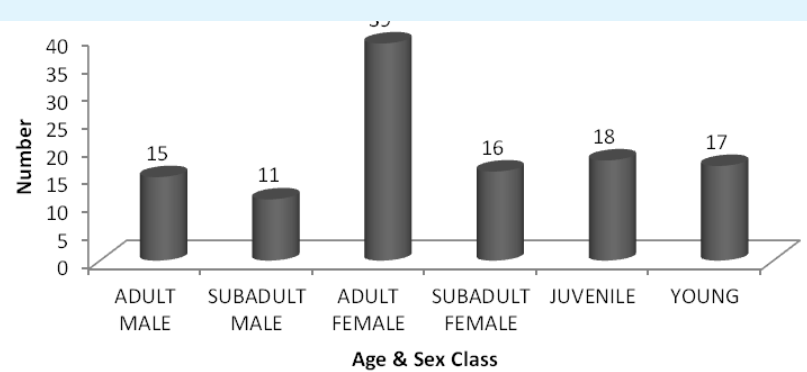

Figure 5: Group Composition of Common Langur.

In the case of Nilgiri langur the group composition of individuals are as like the same of Bonnet macaque and common langur. The highest sighting of adult female (34) was sighted followed by adult male (13) and sub adult female (12). Very few sighting (7) of sub adult male and juveniles were seen (Figure 6). The sex ratio of adult male and adult female is 1:2.6.

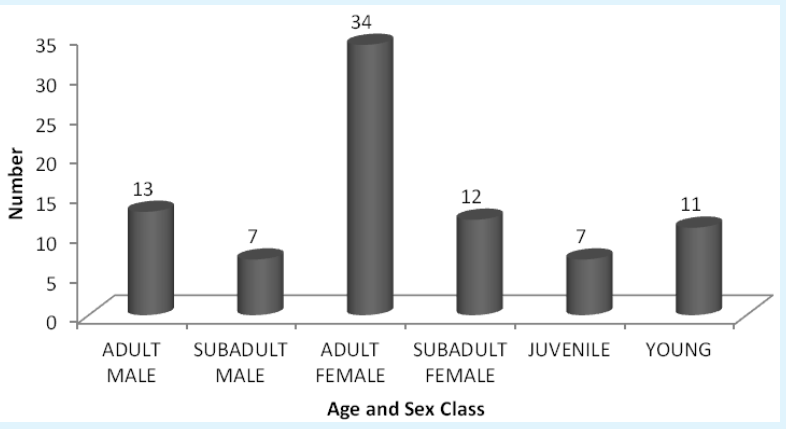

Figure 6: Group Composition of Nilgiri Langur.

Comparison of age and sex class of the adult female of all three primates such as bonnet macaque, common langur and Nilgiri langur is higher than the adult males. Likewise, the sub adult male, sub adult female, juvenile and young ones of all three primates are also showing the same trends (Figure 7).

Analysis of variance (ANOVA) was tested to find out the different size class (adult, sub-adult and juvenile) distribution of three species of primates in the study area. The results show that different Age and sex class of primates was highly significant: $F=11.35, d f=17, p<$ 0.0009 ) in the study area.

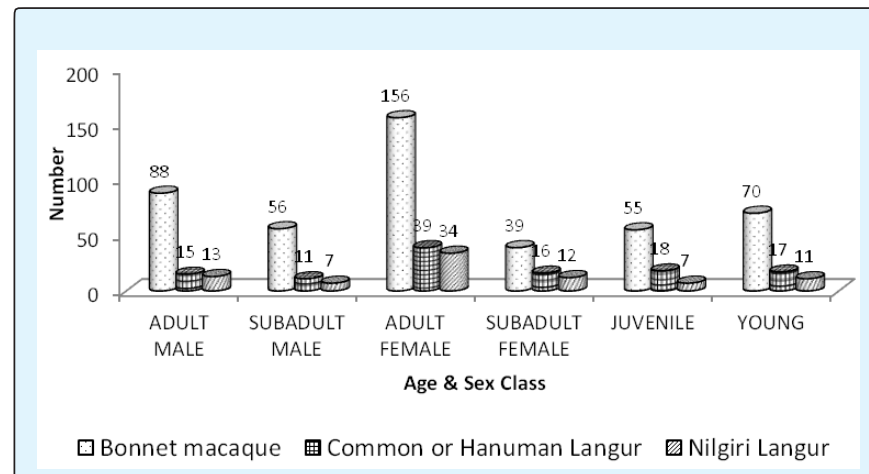

Figure 7: Comparison of Age and Sex Class of South Indian Primates.

\section{Habitat Preference}

Habitat preference of the bonnet macaque in the study area is mostly on plantation (47\%) followed by moist deciduous forest (38\%) habitats. Only very low utilization of habitats such as evergreen and shoal forests is seen by bonnet macaque (Figure 8).

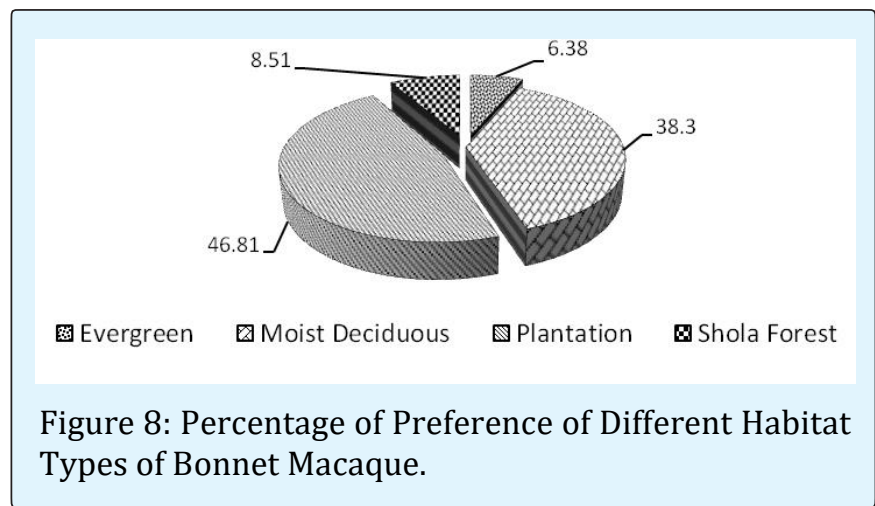

In the case of common langur the preference of habitat is mostly on plantation (42\%) followed by dry deciduous forest (33\%) and moist deciduous forest (25\%) (Figure 9).

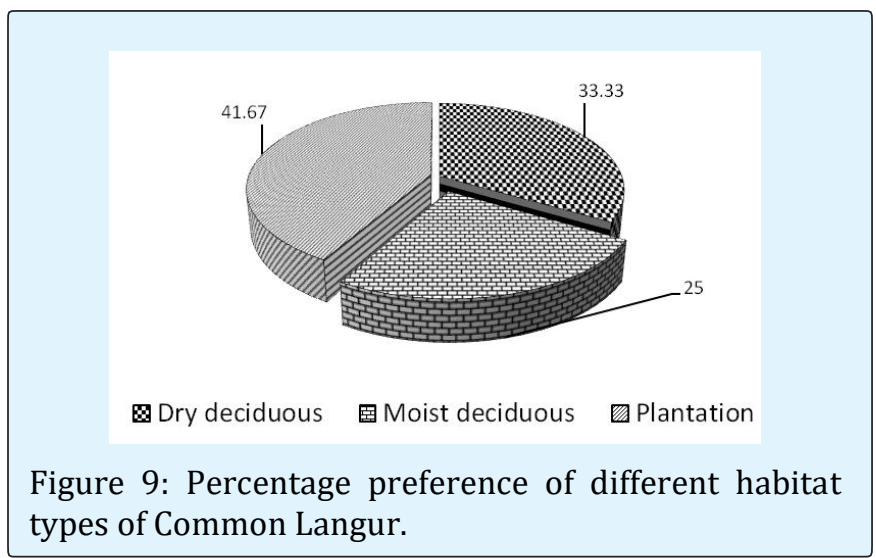


The habitat preference of Nilgiri langur is mostly on shola forests $(67 \%)$ followed by moist deciduous $(22 \%)$ and plantation $(11 \%)$ respectively (Figure 10$)$.

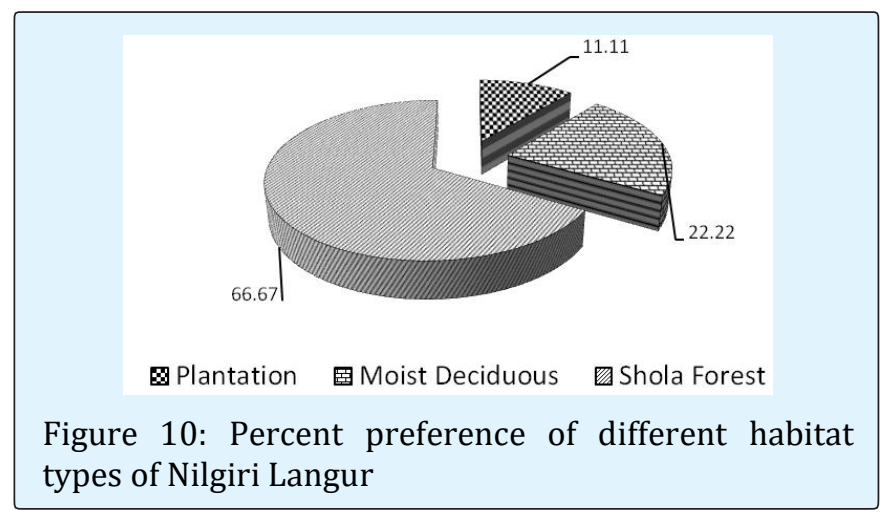

The analysis of the data shows huge variation within the habitat types. The dominance of all the three species of primates shows huge variation whereas the Shannaon Index of the same also shows difference (Table 1).

\begin{tabular}{|c|c|c|c|c|}
\hline Animal & $\begin{array}{c}\text { Total No. } \\
\text { of troops }\end{array}$ & $\begin{array}{c}\text { Dominance } \\
\left(\mathbf{D}^{\wedge} \mathbf{)}\right.\end{array}$ & $\begin{array}{c}\text { Shannon } \\
\text { Index }^{\wedge}\end{array}$ & $\begin{array}{c}\text { Evenness } \\
\mathbf{e}^{\wedge} \mathbf{H} / \mathbf{S}\end{array}$ \\
\hline $\begin{array}{c}\text { Bonnet } \\
\text { Macaque }\end{array}$ & 47 & 0.38 & 1.11 & 0.76 \\
\hline $\begin{array}{c}\text { Common } \\
\text { Langur }\end{array}$ & 12 & 0.35 & 1.08 & 0.98 \\
\hline $\begin{array}{c}\text { Nilgiri } \\
\text { Langur }\end{array}$ & 9 & 0.51 & 0.85 & 0.78 \\
\hline
\end{tabular}

Table1: Analysis (Shannon Index) within the habitat types used by primates.

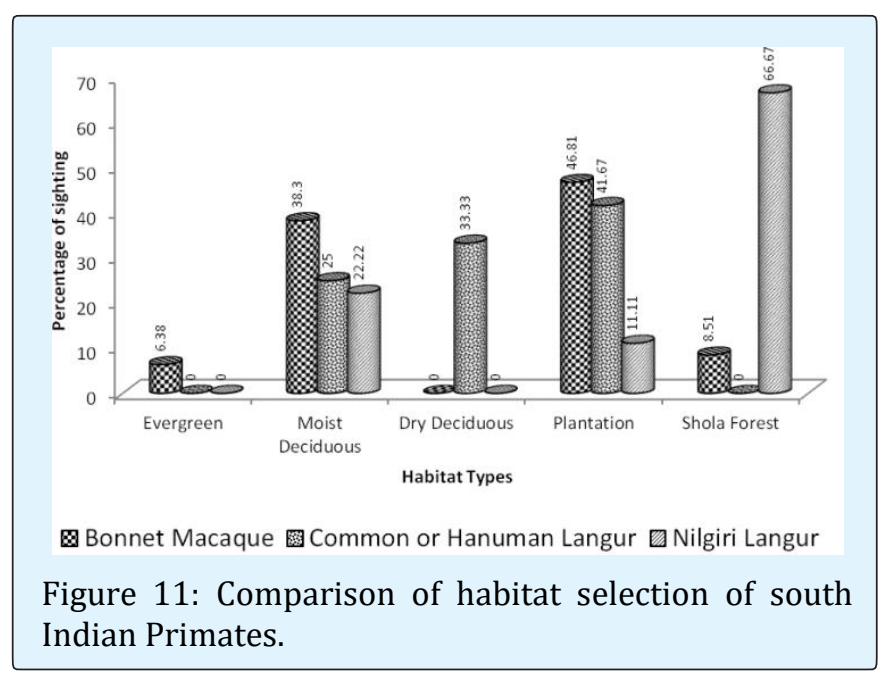

Comparisons of habitat selection by three south Indian primates are shows that bonnet macaque and common langur prefers mostly on plantations followed by moist deciduous habitat. Whereas the Nilgiri langur prefer mostly on shola forests (Figure 11). Analysis of variance was employed to find out the variations of habitat preferences of three primates. The analysis shows that there is no significant differences among the habitats $(\mathrm{F}=1.16, \mathrm{df}=14, \mathrm{p}<0.3844)$, variations was not found between the species.

\section{Activity Budget}

The activity budget of bonnet macaque is mostly on resting (40\%) followed by feeding (28\%), walking (16\%) and playing (12\%) respectively. Very low percent of other activities are jumping and parental care activities (Figure 12).

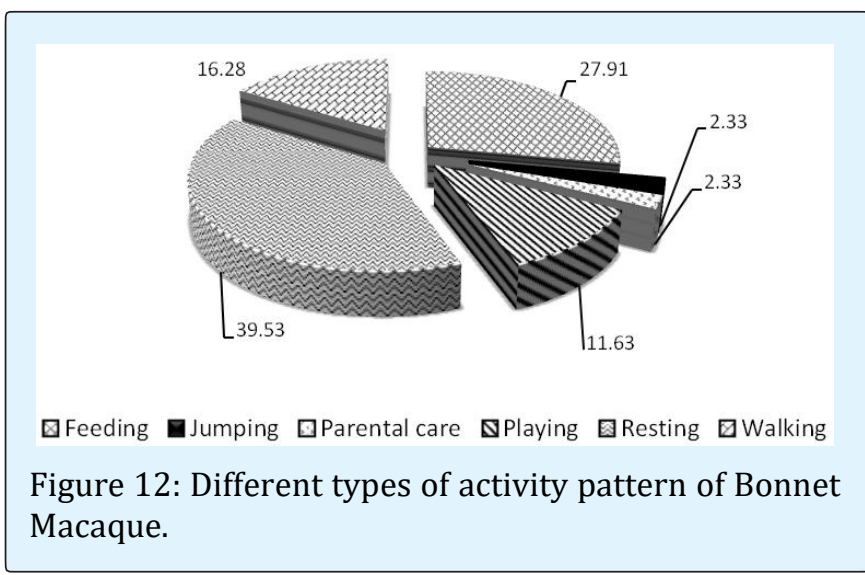

The activity pattern of common langur is mostly on feeding (42\%) followed by resting (33\%), jumping (17\%) and parental care (8\%) respectively (Figure 13).

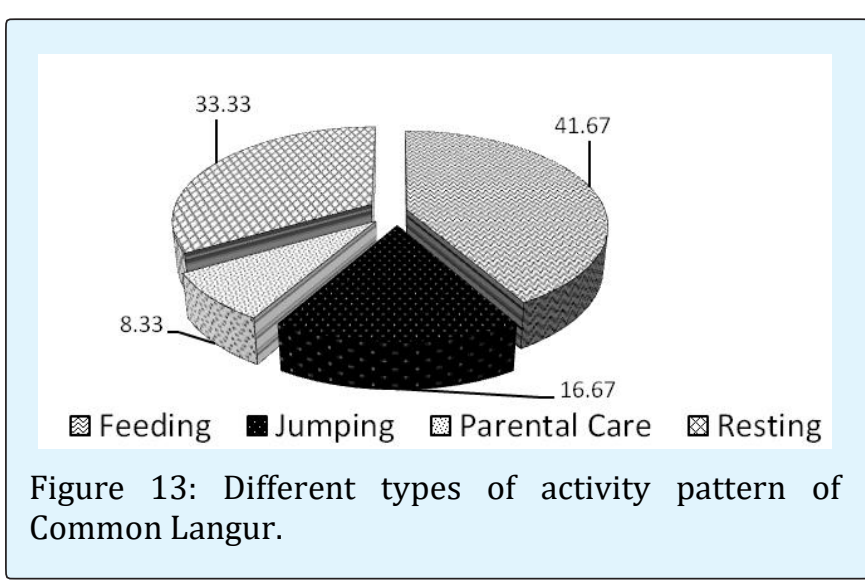

In the case of Nilgiri langur, it spent most of the time on jumping (44\%) followed by resting (33\%) and feeding $(22 \%)$ activities respectively (Figure 14$)$. 


\section{International Journal of Zoology and Animal Biology}

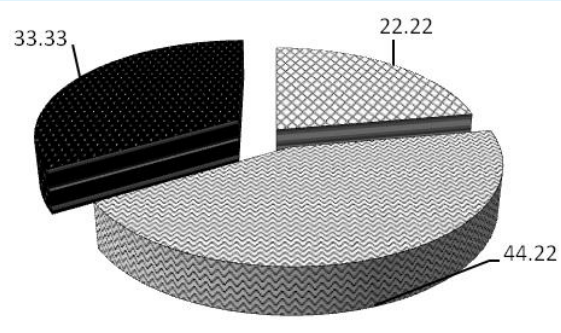

Feeding 图 Jumping Resting

Figure 14: Different types of activity pattern of Nilgir Langur.

Comparison of different activities of all the three primates in the study area shows they spent most of their time on resting activities followed by feeding. In the case of Nilgiri langur it mostly does jumping in the branches of trees. Parental care behavior was observed in common langur and bonnet macaques (Figure 15). Analysis of variance was done to find out the different between the activities of three primates. The different between the activity of primates was highly significant $(\mathrm{F}=5.14, \mathrm{df}=17$, $\mathrm{p}<0.009$ ).

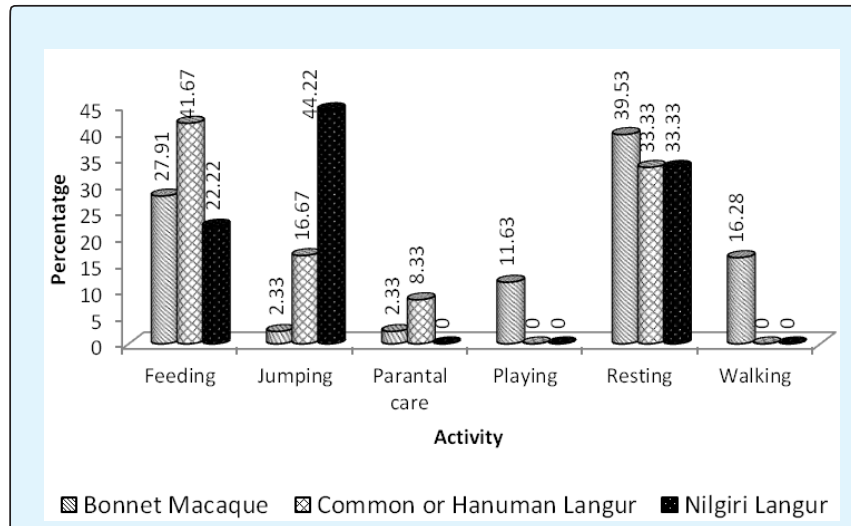

Figure 15: Comparison of different activities observed by the south Indian primates.

\section{Food and Feeding}

Food habits of the bonnet macaque was observed during the time of the study and the macaques feed mostly on foliage of different species of trees (30\%) followed by grains (19\%). Fruits of the trees and agricultural areas and tubers of the agriculture field have been observed equally (16\%). It also feed on insects from the bark of the trees and vegetables (Figure 16).

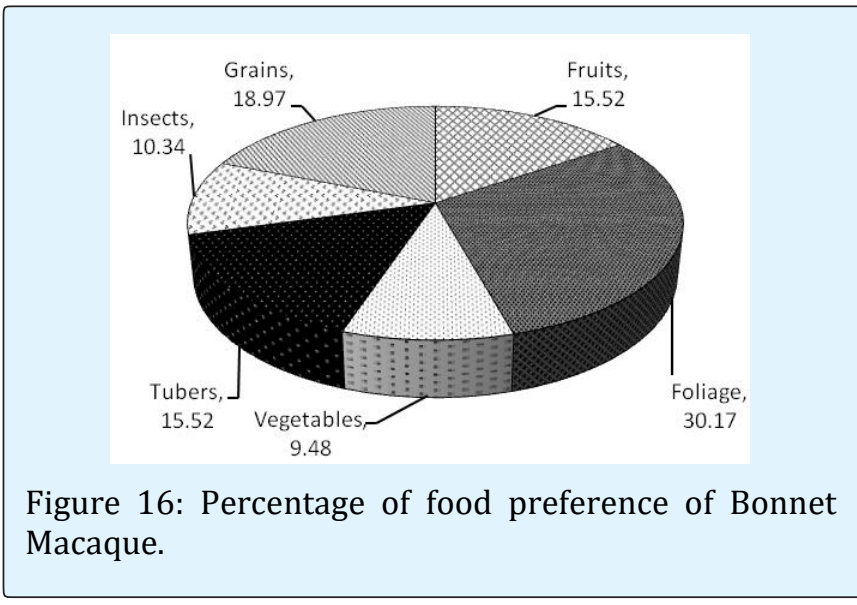

Common langur feed mostly on foliage of trees (42\%) followed by fruits of different species of trees (29\%), grains of agriculture fields (16\%) and insects and other animal matters (13\%) respectively (Figure 17 ).

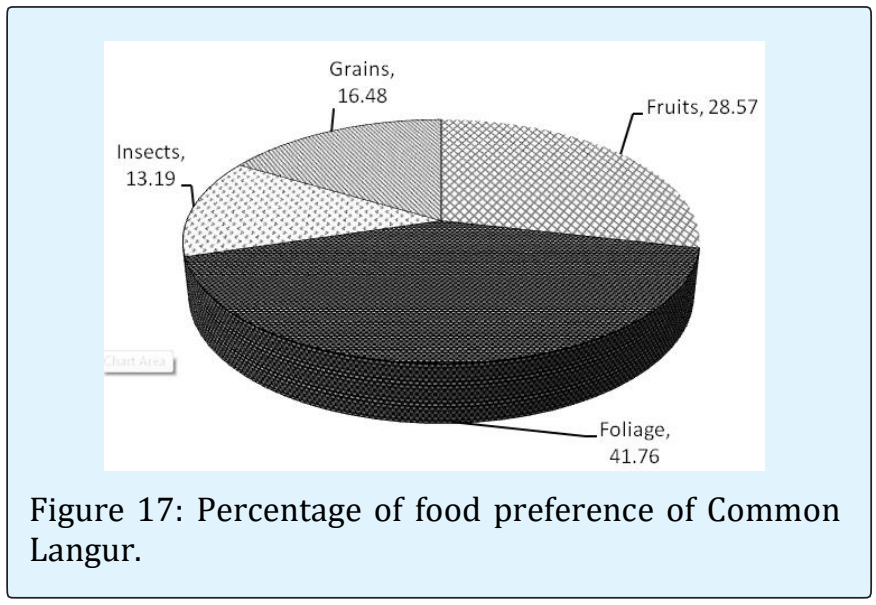

Percentage of different types of foods by the Nilgiri langur was observed and it shows that mostly it feed on Foliage of tree species (45\%) followed by fruits (21\%), flowers $(22 \%)$ and twigs of the trees $(12 \%)$ respectively (Figure 18).

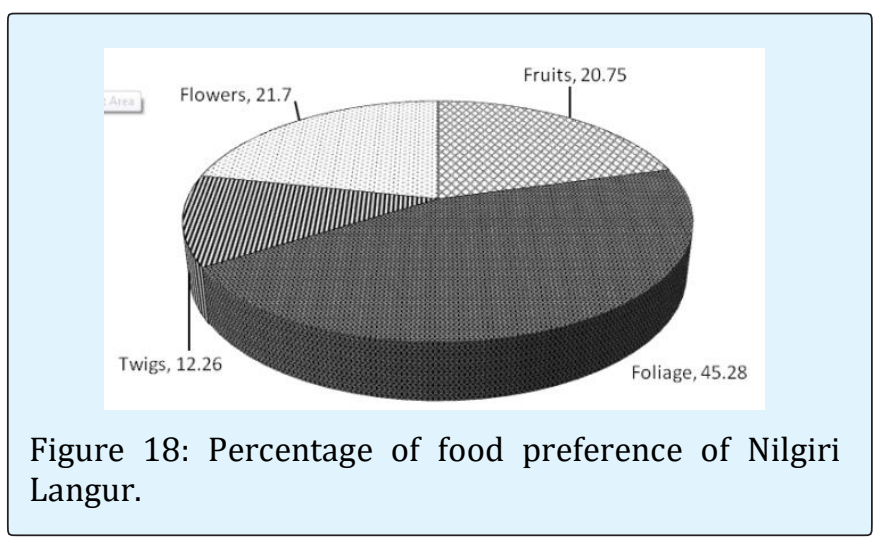




\section{International Journal of Zoology and Animal Biology}

Comparison of food preference by bonnet macaque, common langur and Nilgiri langur were shows that they mostly prefer the foliage of different trees species followed by fruits. Bonnet macaque and common langur fed on insect and other animal maters. Only bonnet macaque have been observed to raid agriculture crops and feed on the vegetables and tubers. Interestingly the Nilgiri langur feed on twigs and flowers of some of the tree species (Figure 19). Analysis of variance was employed to find out the variations of feeding behaviour of three primates. The analysis shows that significant variations $(F=6.37, d f=23, p<0.001)$ was found between the species.

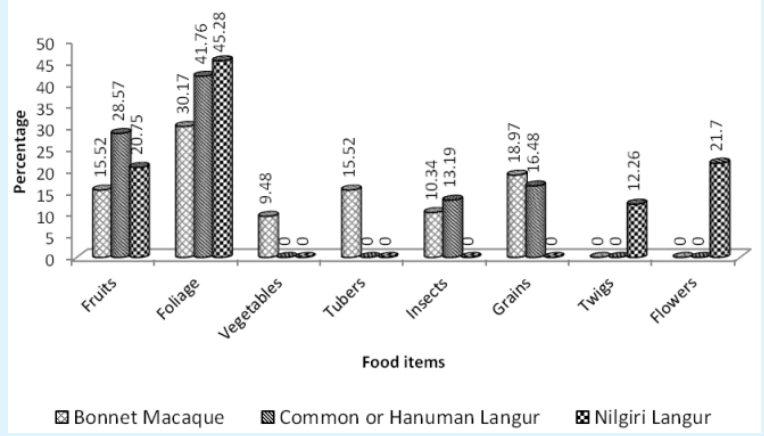

Figure 19: Comparison of food materials of the south Indian primates.

\section{Discussion}

The primate species of India vary in shape, size, population status, habitat requirements, and can be segregated into various groups such as primates of special status, primates which are still abundant, primates with uncertain population and those which are threatened with extinction. Present study reveals that the status and distribution of three primate species namely bonnet macaque, common langur and Nilgiri langur in the adjacent regions of Gudalur areas of Nilgiris of these the Nilgiri langur has got an endangered status, while the bonnet macaque is rather abundant South Indian species, and common langur has been found most of the parts in the country [34].

Bonnet macaques are quite adapted to the highly varied forest types of Peninsular India, It is found both in the jungles, country side and towns. It is more common in the rural and suburban areas [4]. Bonnet macaque occupies all major habitats like the deciduous forests, road ways, farm fields, villages, cities. Kurup (1981)[15] estimated a population of about 8450 bonnet macaque troops in the country side of the four southern states of India namely Andhra Pradesh, Karnataka, Tamil Nadu and Kerala.

During the present study period the bonnet macaques were sighted from rural areas adjacent to Gudalur, moist deciduous forests, plantation and agriculture fields. The distribution of bonnet macaque is more random and it is found in almost all types of forests. This can be seen in the peripheral areas of the forest areas often becoming a minor pest. Kurup (1981) [15] has reported the average troop size of bonnet macaques as 26.2 , while in the present study it comes only about 15 .

The present study also reveals that the bonnet macaques has been feed on foliage, fruits, tubers, grains, etc. According to Krishnan (1972) [16] bonnet macaques are omnivorous feeding on leaves, young shoots, flowers and fruits, eggs of birds, grass hoppers and occasionally on lizards. Rahman and Parthasarathy (1975) [35] reported the food and feeding of bonnet macaque as depending upon the resource availability and its distribution. Troop size in monkeys is an important factor in food resource utilization depending on the availability of the spatial and temporal distribution of food resource. The size and the structure of social group, predator pressure and population density may affect the foraging strategies of monkeys. Each factor has influenced the bonnets at various habitats.

Nilgiri langur is an endangered primate endemic to the southern Western Ghats. It generally inhabits the sholas and their range is continuous throughout the monsoon forests in the Western Chats $[9,36]$. In the present study, it is estimated that the Nilgiri langur population of 11 troops with 84 individuals having a mean group size of 5.68. According to Poirier (1970) [37] who made a detailed study of the bisexual troop reports having an average of 8-9 individuals per troop. He could identify unisexual groups and in the present study reveals the occurrence of six solitary males in different areas. These solitary males live away from bisexual troops for a period of time and probably they may migrate into adjacent troops maintaining an interbreeding population.

Nilgirl langur can be considered as a vegetarian, but they may occasionally eat insects [4]. The present study reveals its strict vegetarian nature. All feeding observations confine to plant materials. Even though $45 \%$ of the feeding observations are on foliage, the feeding data is insufficient to test its insectivorous status in the study area. According to Krishnan (1972) [16] the main food of Nilgiri langur consists of leaves, flowers, buds, fruits, 


\section{International Journal of Zoology and Animal Biology}

seeds, bark and stems of various plants and the bulk of the diet being derived from shrubs and they prefer leaves for their food. However, the preferred food plants of Nilgiri langur change with the seasons [38].

Studies conducted elsewhere on common langur had shown different estimates of population density. John singh (1983) [20] were estimated the lowest density of 7.5 individuals $/ \mathrm{km} 2$ in Bandipur Tiger Reserve followed by Bagchi, et al. (2003) [39] estimated 21.7 individuals $/ \mathrm{km}^{2}$ in Ranthambore Tiger Reserve, 28.3 individuals/km2 in Bori-Satpura Tiger Reserve by Edgaonkar (2008) [40] and highest density of 82.5 individuals/km2 were estimated in Pench Tiger Reserve by Aniruddha, et al. (2010). Based on this perhaps the tropical dry deciduous and moist deciduous habitats harvests reliably high density of common langurs in India, which are exist in Satpura and Mikal landscape. The differences in the density in different studies could be use of different study methods and probably also due to habitat quality of study areas and many other factors such as season, annual variations and observer differences [41]. The population density, group size and composition of social groups vary geographically because of habitat structure and food availability [42]. The present study shows that the abundance and group composition of common langur is distributed very low population in the study areas.

The average group size of common langur was recorded in the study area is about 12 to 13 individuals where as in Melghat 6.21 \pm 0.9 and elsewhere frequently were recorded the high proportion of groups ranging between 1-10 individuals, a male with multi female social groups. When compared to other places consequently the mean group size of 6.5 individuals was estimated by Kumara and Mewa Singh (2003) [43] in BrahmagiriMakut in Western Ghats, and averaging of 7.9 individuals was recorded in Pench Tiger Reserve by Aniruddha et al. (2010). Similar or slightly larger average group sizes (10.31 individuals) have been recorded elsewhere in SiriHonnavara Kumara and Mewa Singh, (2003) [43]. Variation in group size in different habitats may be due to the difference in the distribution, abundance and quality of the food resources in the habitat and the population density [20]. The depletion of food plants important to the langurs due to the collection of non-timber forest produce (NTFP) was found to be the most vulnerable threats [43]. The inhabitants are mostly depending on minor forest products for their daily needs. Degradation of habitat as a result of fuel wood collection, anthropogenic pressure and forest fire would be the immediate threat for the
Hanuman langurs and their habitats in Indian subcontinent.

\section{Conclusion and Summary}

The Western Ghats provide a striking example of primate endemism and it holds a highly fragmented population of India's most endangered primate species namely the lion-tailed macaque, Macaca silenus and Nilgiri langur Trachypithecus johnii. The distribution of Common or Hanuman langur, Semnopithecus entellus extends up to the southern region of the Western Ghats. A study on primates was conducted in the villages surrounded by natural forest areas of Gudallur region.

Hunting of primates as agricultural pests is a major problem and also menace to the tourism areas. The bonnet macaques can become significant crop raiders in certain areas and are persecuted as such. Habitat destruction is the most significant threat to the survival of primates in India. However, certain species can survive in disturbed habitats, but the long-term consequences on reproduction and survival are unknown. Differences in population density, demography, and social structure can be related to habitat quality at different reserve forests with varying degree of disturbance. Detailed studies that combine field surveys and phylogenetic studies are needed to determine the primate distribution and status in the rain forests in Gudalur region which is adjacent to Mudumalai Tiger Reserve in Tamil Nadu and Wayanad Wildlife Sanctuary in Kerala.

\section{Acknowledgements}

The authors convey their sincere thanks to the Tamil Nadu Forest Department for given permission to conduct the study.

\section{References}

1. Pascal JP, Ramesh BR, Franceschi DD (1988) The wet evergreen forests types of southern Western Ghats of India. Tropical Ecology 45(2): 281-292.

2. Chandran MDS (1997) On the ecological history of the Western Ghats. Curr Sci 73(2): 146-155.

3. Mohnot SM (1978) The conservation of nonhuman primates in India. In: Chivers DJ, Lane Petter W (Eds.), Recent Advances in Primatology, Academic, London 72: 47-53. 


\section{International Journal of Zoology and Animal Biology}

4. Roonwal ML, Mohnot SM (1977) Primates of south Asia: Ecology, Sociobiology and Behaviour. Harvard University Press, Cambridge, Massachusetts, pp: $337-$ 411.

5. Pocock RI (1928) The langurs or leaf monkeys of British India. Part I. J Bombay nat Hist Soc 32: 472504.

6. Hutton AF (1949) Notes on the snakes and mammals of the Highway Mountains, Madurai district, South India, Part I1 Mammalia. J Bombay nat Hist Soc 48: 651-694.

7. Poirier FE (1969) The Nilgiri langur (Presbytis johni) troop: Its composition structure, function and change. Folia Primatologica, 10: 20-47.

8. Kurup GU (1971) A preliminary ecological survey of the Periyar Wildlife Sanctuary. Kerala State. Cheetal 13: 5-18.

9. Kurup GU (1975) Status of the Nilgiri langur. Preshytis johni in the Anamalai. Cardamom and Nilgiri Hills of the Western Ghats. J Bombay nat Hist Soc 72: 21-29.

10. Kurup GU (1978) Distribution, habitat and status survey of the lion-tailed macaque, Macaca silenus. J Bombay nat Hist Soc 75: 321-340.

11. Green S, Minkowski K (1977) The lion-tailed monkey and its South Indian rain forest habitat. In: Rainier, Bourne GH (Eds.), Primate Conservation, Academic Press, New York, pp: 289-337.

12. Karanth KU (1985) Ecological status of the lion-tailed macaque and its rain forest habitats in Karnataka, India. Primate Conserv 6: 73-84.

13. Ali $R$ (1985) An overview of the status and distribution of the lion-tailed macaque. In: Heltne PG, Alan R. Liss (Eds.), The Lion-tailed Macaque: Status and conservation, New York, pp: 1325.

14. Ali R (1986) Feeding ecology of the bonnet macaque at Mundanthurai sanctuary, Tamil Nadu, India. J Bombay nat Hist Soc 83: 98-110.

15. Kurup GU (1981) Report on the census survey of rural and urban populations of non-human primate of South India. Zoological Survey of India. In: Mohnot, Lave Petter W (Eds.), Academic Press, New York, pp: 47-53.
16. Krishnan M (1971) An ecological Survey of the Large Mammals of Peninsular India. Bombay natur Hist Soc J 68(3): 503-555.

17. Singh M, Akram N, Pirta RS (1984) Evolution of demographic pattern in the Bonnet Macaque (Macaca radiata). In: Roonwal ML, Mohnot SM, Rathore NS (Eds.), Current Primate Researches, Zoology Department, Jodhpur University, Jodhpur, pp: 7-16.

18. Pirta RS, Prakash P, Singh M (1981) A population study of two species of non-human primates: Macaca mulatta and Macaca radiata. Bombay nat Hist Soc J 77: 429-434

19. Sinha A, Dutta Roy A (2000) Ekam adwitiyam: The socio-ecology of uni-male troops of wild Bonnet Macaques (Macaca radiata). NIAS Working Paper, National Institute of Advanced Studies, Bangalore.

20. Johnsingh AJT (1983) Large mammalian preypredator relationship in Bandipur Tiger Reserve. J Bombay nat Hist Soc 80: 1-57.

21. Gupta AK (2001) Non-Human Primates of India: An Introduction. Envis Bulletin: Wildlife and Protected Areas 1(1): 1-29.

22. Karanth KU, Sanquist ME (1995) Prey Selection by Tiger, Leopard and Dhole in Tropical Forests. British Ecological Society. J of Anim Ecol 64(4): 439-450.

23. Borah J, Deka K, Dookia S, Gupta RP (2009) Food habits of dholes (Cuon alpinus) in Satpura Tiger Reserve, India. Mammalia 73(2): 85-88.

24. Champion HG, Seth SK (1968) A Revised Survey of the Forest Types of India. Government of India Press, New Delhi.

25. Kumar A (1987) The ecology and population dynamics of the lion-tailed macaque (Macaca silenus) in South India, University of Cambridge.

26. Krishnamani R (1994) Diet composition of the bonnet macaque in a tropical dry evergreen forest of Southern India. Tropical Biodiversity 2(2): 285-302.

27. Burnham KP, Anderson DR, Laake JL (1980) Estimation of density from line transects sampling of biological populations. Biometrical Journal 24(3): 1202.

28. Whitesides GH, Oates JF, Green SM, Kluberdanz RP (1988) Estimating primate densities from transect in 
a west African Rain Forest: A comparison of techniques. J Anim Ecol 57(2): 345-367.

29. Richard AF (1978) Behavioural variation: Case study of a Malagasy lemur. Lewisburg, PA: Bucknell University Press pp: 213.

30. Fragaszy DM, Boinski S, Whipple J (1992) Behavioral sampling in the field: Comparison of individual and group sampling method. Ame J of Primatology 26(4): 259-275.

31. Neal W, Forthman D (1996) Activity budgets of Angolan colobus Colobus angolensis in a naturalistic zoo habitat. African Primates 2: 19-22.

32. Altmann J (1974) Observational study of behaviour: Sampling methods. Behaviour 49(3-4): 227-267.

33. Chapman CA, Fedigan LM (1990) Dietary difference between neighboring Cebus capucinus groups; local traditions, food availability or responses to food profitability. Folia Primatol 54(3-4): 177-186.

34. Ramachandran KK (1995) Status survey of primates in Shendurney Wildlife Sanctuary and adjacent areas. KFRI Research Report 106: 34.

35. Rahman H, Parthasarathy MD (1975) Home range, core areas and roosting places of bonnet monkeys living in cultivated gardens. Bull Ethol Soc India 1: 1620 .
36. Poirier FE (1968) Nilgiri langur (Presbytis Johni) territorial behavioural primates. Inuyama 351-364.

37. Poirier FE (1970) Dominance structure of the Nilgiri langur (Presbytis johni) of South India. Folia Primatologica 12: 161-186.

38. Horwich RH (1972) Home ranges and food habits of the Nilgiri langur. Prebytis johni. J Bombay nat Hist Soc 69: 255-267.

39. Bagchi S, Goyal SP, Sankar K (2003) Prey abundance and prey selection by tigers (Panthera tigris tigris) in a semi-arid, dry deciduous forest in western India. J of Zool 260(3): 285-290.

40. Edgaonkar A (2008) Ecology of Leopard (Panthera pardus) in Bori Wildlife Sanctuary and Satpura National Park, University of Florida, India, pp: 135.

41. Newton P N (1989) Associations between langur monkeys (Presbytis entellus) and chital deer (Axis axis): Chance encounters or a Mutualism?. Ethology 83(2): 89-120.

42. Raemakers J (1980) Causes of variation between months in the distance travelled daily by gibbons. Folia Primatol 34(1-2): 46-60.

43. Kumara HN, Mewa Singh (2003) Distribution and Abundance of Primates in Rain Forests of the Western Ghats, Karnataka, India and the Conservation of Macaca silenus. Int J of Primatol 25(5): 1001-1018. 